\title{
The Role of Education Management in Improving the Quality of Excellent School Education
}

\author{
Mona Novita \\ STAI Yasni Bungo \\ E-mail: novitamona58@yahoo.com
}

\author{
Muhammad Solihin \\ STAI Yasni Bungo \\ E-mail: muhammadsolihin@staiyasnibungo.ac.id
}

\begin{abstract}
One of the main themes in discussing excellent schools is regarding "the process of making the students to excellent" and quality assurance managemnet of excellent schools. This paper examines the nature of superior schools and quality assurance management of superior schools, which consists of: (1) a harmonious school atmospehre, (2) management based on supervision (control management), (3) determination to improvesustainable quality, (4) the school work reference is productivity (efficient and effective), and (5) tough leadership. Excellent schools are another version of excellent students. In this point, the "student enhancement process" becomes the main goal in achieving quality output. This follows a "System Theory" in Excellent Schools expressed by J. Alan Thomas that negative / bad input, if the enhancement process + (positive), it will result in almost + (excellent) output. The process of enhancement input in superior schools is: (1) the ability of professional teachers consisting of professional competence, competence in learning, mentoring, communication with students and in evaluating, (2) the curriculum uses a differentiation curriculum and links subject matter with modern inventions in accordance with current technological developments, (3) extracurricular programs and (4) collaborative networks with educational institutions.
\end{abstract}

Keywords: excellent schools, student enhangement process, quality management.

\begin{abstract}
Abstrak: Salah satu tema utama dalam pembahasan tentang sekolah unggulan adalah mengenai "proses pengunggulan siswa" dan manajemen penjaminan mutu sekolah unggulan. Makalah ini mengkaji tentang hakikat sekolah unggulan dan manajemen penjaminan mutu sekolah unggulan yang terdiri dari: (1) iklim sekolah yang harmonis, (2) manajemen yang berbasis pengawasan (control management), (3) tekad untuk meningkatkan mutu secara terus menerus (sustainability), (4) acuan kerja sekolah adalah produktivitas (efficient dan effektive), dan (5) kepemimpinan yang kuat (leadership). Sekolah unggulan merupakan versi lain dari pengunggulan siswa. Disini, "proses pengunggulan siswa" itu yang menjadi sasaran utama dalam mencapai output yang berkualitas. Hal ini mengikuti sebuah "Teori Sistem" dalam Sekolah Unggulan yang diungkapkan oleh J. Alan Thomas bahwa input yang negatif/ buruk, apabila Proses pengunggulannya + (positif) maka akan menghasilkan output yang cencerung + (Unggul). Adapun proses pengunggulan input dalam sekolah unggulan adalah: (1) kemampuan guru yang profesional yang terdiri dari kompetensi
\end{abstract}


profesional, kompetensi dalam pembelajaran, pembimbingan, komunikasi dengan peserta didik dan dalam mengevaluasi, (2) kurikulum menggunakan kurikulum diferensiasi dan mengkaitkan materi-materi pelajaran dengan penemuan modern sesuai dengan perkembangan teknologi saat ini, (3) program ekstrakurikuler dan (4) jaringan kerjasama dengan pihak lembaga pendidikan.

Kata-kata kunci: sekolah unggulan, proses keunggulan siswa, manajemen mutu.

\section{Introduction}

The low quality issue of Indonesian people is no longer a new problem in educational institutions. Every time the Human Development Index report released, the quality position of our Human Resources (HR) is always at the bottom. In 2015 United Nations Development Programs (UNDP) report, Indonesia is still in the group of countries with a medium human development level. Previously, it could be seen that Indonesian quality of education related to basic literacy (reading, mathematics and science), was still left behind from neighboring countries. In a more detailed report from the Organization for Economic Cooperation and Development (OECD) on the PISA (Program for International Student Assessment) which they held to measure the quality, equity and efficiency of education at schools, Indonesia ranks 64 th out of 65 countries ${ }^{1}$.

Why has the quality of education been a matter of big concern in Indonesia from the past to now? The answer is because Indonesia is in a position of siege by superior developing countries, such as in the western part of Indonesia, there are The United States, Australia in the south, and Japan in the north. These three countries can advance, because they excel in three ways: (1) Human Resources, (2) Excellence Technology and (3) Money ${ }^{2}$

Referring to the three things mentioned, it is certainty that we will be left far behind. This is because we are not superior yet in terms of:

First, money, which is the biggest obstacle faced by Indonesia in achieving educational excellence. Moreover, the latest data shows that Indonesia is included in the lower middle class category of economic sector. ${ }^{3}$ Although the government has issued a regulation that at least $20 \%$ of the State Revenue and Expenditure Budget (APBN) must be allocated for education ${ }^{4}$. This obstacle is increasingly felt by talented, super smart, and genius Indonesian students who come from low economic family who cannot study in excellent schools. This is because superior schools are only intended for students with high average socio-economic status which seem to be

${ }^{1}$ Hatta Saputra, Pengembangan Mutu Pendidikan Menuju Era Global, Bandung: Smile's, 2016, p. 49

2 Maswardi Muhammad Amin \& Yuliananingsih, Manajemen Mutu Aplikasi dalam Bidang Pendidikan, Yogyakarta: Media Akademi, 2016, p. 28

${ }^{3}$ Dede Rosyada, Madrasah dan Profesionalisme Guru: dalam Arus Dinamika Pendidikan Islam di Era Otonomi Daerah, Jakarta: Kencana, 2017, p. 31

4 Bambang Sumintono, Sekolah Unggulan: Pendekatan Pengembangan Kapasitas Sekolah, Jurnal Manajemen Pendidikan, Vol. 2, No.1, p. 2. 
exclusive because they are sponsored by conglomerates, big businessmen and representatives of foreign countries. This fact has violated Article 4 of the National Education System Law (UUSPN) No. 20 of 2003 concerning the spirit of democratization of education which demands justice.

The second is Human Resources. The problem above is an indication of humiliation or injustice towards humans. Students with good academic abilities but come from poor families are not able to study in excellent school because financial matter. How about students with poor academic abilities and come from families with poor socio-economic status? Will they continue to be victims of this country's educational injustice? Meanwhile, if we count the percentage of successful school performance that excels in favoring students with good academic abilities and coming from rich families who are nutritionally very luxurious? That is what encourages me to study the issue of excellent schools.

Responding to this, the government through the Minister of Education and Culture Regulation No. 17 of 2017, provides a good news to Indonesian people regarding the elimination of education by implementing a zoning system. $90 \%$ of students must enter the school whose radius is closest to their home address based on their family card (KK), or through the district system or agreement between regional heads. In terms of human resources, Muhadjir Effendy as Minister of Education and Culture stated that there should no longer be school cessation. This is a very challenging breakthrough for the creation of excellent school that is conceptually not superior in its resources but in the process of rolling is equalized and even exceeds the excellent school referred to. ${ }^{5}$

Current educational practices often fail to meet the requirements needed to face globalization and its various demands. ${ }^{6}$ Some important points that must be considered by all implementers of educational institutions are educational institutions are public organizations that are eventually non-profit or not business-oriented and increase profits. The emphasis point of the educational staff is public services such as academic administration services related to the process of implementing education.

This excellent school breakthrough has not been recently carried out either by the government or by the private school; almost all regions in this country already have excellent schools. As quoted from the buahhatiku.com site, regarding the List of Excellent School of all Senior High School in Indonesia. Those are SMA Taruna Nusantara Magelang, SMAN 8 Jakarta, SMAN 3 Bandung, MAN Insan Cendekia Tangerang, SMAN 3 Semarang, SMAN 1 Teladan Yogyakarta, SMAN 5 Surabaya, SMAN 4 Denpasar, SMAN Plus Riau and SMAK 1 BPK Penabur Jakarta. ${ }^{7}$ Completing these data, last year an excellent high school in Papua province was opened. It is SMA Negeri

\footnotetext{
${ }^{5}$ Amin \& Yuliananingsih, Manajemen Mutu, p. 30.

${ }^{6}$ Hatta Saputra, Op. Cit, p. 30.

${ }^{7}$ Anonim, Inilah Daftar SMA Unggulan Terfavorite se-Indonesia, http://buahhati.com, accessed on $12^{\text {th }}$ January 2018.
} 
Unggulan Dawai with accreditation B, the KTSP curriculum, and implemented School Based Management (SBM) ${ }^{8}$. SBM is one of the top management OF school quality improvement besides Community Based Management and Strategic Management. ${ }^{9}$ With the concept of change towards quality improvement in the context of school-based quality management, it can increase school autonomy and professionalism in education domain ${ }^{10}$.

Excellent schools are not superior schools that seem to be exclusive and have students whose high economic status. But schools that have unexecellent school resources, but able to produce excellent graduates like those produced by excellent schools ${ }^{11}$. Is it impossible to happen? Maybe that is the question that arises in our minds, considering that the problem of Indonesia's economy and human resources is still low. It is a classic problem that never ends, as discussed earlier. However, if it is viewed from the concept of excellent school, it is certain that this is not only a dream that is difficult to realize. Conceptually, the excellent school is another version of excellent students. Here, the process of enhancing students is the main target in achieving quality output.

This follows a System Theory in Excellent Schools expressed by J. Alan Thomas that $\mathrm{A}$ if the (input) is negative or bad, if $\mathrm{P}$ (the Process) is + (positive) it will produce $\mathrm{K}$ (Output) that means excellent ${ }^{12}$. The process of its excellence must be the same as that of a excellent school, or even more than that of an excellent school which is used as a reference because its resources are not excellent. This means that it is not the student economy that determines the quality of the graduates as a whole. This is in line with Nanang Fattah's opinion that excellent schools are schools that are developed in order to achieve excellence in educational output. The advantages in terms of output include thr basic quality (thinking power) and mastery of science ${ }^{13}$.

The goal of these excellent schools will only be achieved if in its implementation these schools apply a quality assurance management model for excellent schools. The aim is that children who have extraordinary abilities and intelligence, special talents, genius and super smart, but with limited financial condition are still given the same treatment and services regardless of differences in skills, ethnicity, rich and poor, interests and talents and graduated as a superior graduate from a superior school ${ }^{14}$. Excellent schools are expected to produce superior human beings who are

\footnotetext{
${ }^{8}$ Direktorat Jenderal Pendidikan Dasar dan Menengah, Data Pokok Pendidikan Dasar dan Menengah SMA Negeri Unggulan Dawai Papua. http:// www.dapo.dikdasmen.kemdkbud.go.id, accessed on 12th January 2018.

${ }^{9}$ Amin \& Yuliananingsih, Manajemen Mutu, p. 43

10 Rohiat, Manajemen Sekolah, Bandung: Refika Aditama, 2008, p. 67.

${ }^{11}$ Amin \& Yuliananingsih, Manajemen Mutu, p. 135

12 Ibid, p. 134.

13 Nanang fattah, Sistem Penjaminan Mutu Pendidikan, Bandung; Rosda, 2013,p. 126.

14 Ibid, p.113.
} 
very useful for developing this country. ${ }^{15}$ It is undeniable that every parent wants their children to be excellent and have good achievemnets.

\section{Excellent Schools and Its Main Aspect}

\section{a. The Essence of Excellent Schools}

Ontologically, an excellent school in the perspective of the Ministry of National Education is a school that is developed to achieve excellence in its educational output. To achieve this advantage, input, the education process, teachers, education personnel, management, education services, and their supporting facilities must be directed to support the achievement of these goals. ${ }^{16}$

Excellent schools are another version of excellent students. The establishment of excellent schools is in accordance with the spirit of democratization of education which demands justice. It is not like an excellent school which has excellent resources, both human resources and non-human resources. An excellent school is a school that has inferior resources, but produces excellent graduates. ${ }^{17}$

A superior school can be defined as a qualified school. However, in the observation that in the excellent category there is an implied expectation of the output that students have after leaving the excellent school. This expectation is very important and needed by parents, government, society and even the students themselves, that how far this school output has intellectual, moral and skill abilities that can be useful for society ${ }^{18}$. Thus, it can be concluded that a superior school is a school whose input harvesting process is carried out the same as or even more than a superior school. Superior schools are developed and managed as well as possible by directing all components to achieve better and more competent graduate outcomes than other school graduates by prioritizing the process of excellence as the main determinant of graduate quality.

\section{b. Main Aspects of Excellence Schools}

In essence, management of improving the schools quality is a strategic way to improve the quality of education. The quality of education at schools must be considered and improved to be better and higher quality. This is a challenge that must be responded positively by educational institutions. They are the quality of inputs, processes, outputs and outcomes. And at this time, schools must begin to improve themselves to face the global world demands in

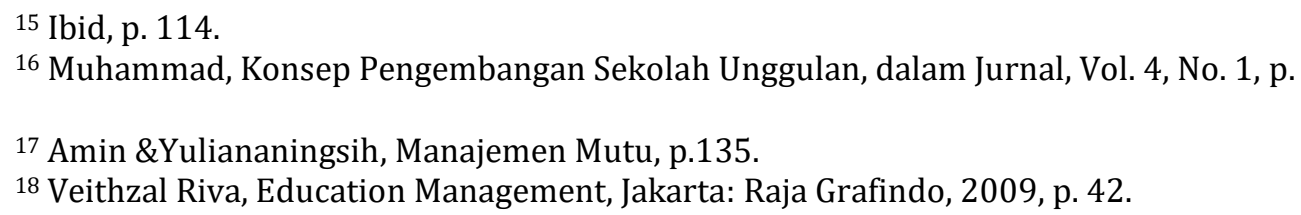


preparing qualified human resources. ${ }^{19}$ This is in accordance with what was expressed by Petrus Trimantara that there are three main aspects of a school to be called excellent school:

1) Input

The input here means the students' intelligence of the brain (Intelligence Quotien), emotional intelligence (Emotional Quotien) and Spiritual Intelligence (Spiritual Quotien) which is measured at school entry selection. Not only students as educational input here, teachers, facilities and infrastructure, learning resources, and rules (school rules) and as well as the teachers.

2) Process

In the process of maximizing excellent school resources, there is a system theory used by J. Alan Thomas, which is as shown below:20

\begin{tabular}{|l|l|l|}
\hline \multicolumn{1}{|c|}{ A } & \multicolumn{1}{c|}{$\boldsymbol{P}$} & \multicolumn{1}{c|}{ K } \\
\hline \hline Excellent $(+)$ & Excellent $(+)$ & Excellent $(+)$ \\
\hline Excellent $(+)$ & Not Excellent $(-)$ & Almost not excellent(-) \\
\hline Not Excellent $(-)$ & Excellent $(+)$ & Almost excellent $(+)$ \\
\hline Not Excellent $(-)$ & Not Excellent $(-)$ & Not Excellent $(-)$ \\
\hline
\end{tabular}

Explanation:

$A=$ Intake (input): Students who have just entered the school (new students Or new students move up to the next class.

$\mathrm{B}=$ Process (Learning Process)

$\mathrm{K}=$ Output (graduate $=$ output): Students who were successfully educated at a certain education level.

Based on the system theory, it can be seen that the excellent intake (A) / input is then given the $\mathrm{P}$ (process) excellenty, it will produce $\mathrm{K}$ (output) / excellent graduate as well. This is also in accordance with the Input-Output perspective stated by Seeley in Fasli Jalal, that the educational output is excellent because the input is excellent, but the weakness is that it ignores students who are not excellent ${ }^{21}$. This is an opportunity for excellent schools to address these problems, as seen in the third row in the table above, it can be seen that the intake $(\mathrm{A})$ is not excellent, but given an excellent $\mathrm{P}$ (Process),

19 Prim Masrokan Mutohar, Manajemen Mutu Sekolah, Jakarta: Aruzzmedia, 2013, 124

${ }^{20}$ Amin \& Yuliananingsih, Manajemen Mutu, p. 134.

${ }^{21}$ Fasli Jalal, Strategi dan Arah Pengembangan Sekolah Unggul: Dirjen Peningkatan Mutu Pendidik dan Tenaga Kependidikan, accessed on $12^{\text {th }}$ January 2018. 
it will produce K (Output) which is also excellent. This is known as a strategy with a Process-Output perspective, which is a perspective that views excellent school educational outcomes to be determined by the process (school structure, environment, corporate culture, effective learning, etc.).

The advantage of this perspective is to pay attention to excellent and non-excellent students. The expected results from the learning process are graduates who are excellent or of high quality. Excellent or qualified graduates are characterized by high final scores, large number of graduates, the number of students continuing studies at a higher level and the number of graduates who are accepted to work in many favorite institutions. ${ }^{22}$

In order to carry out the learning process, a teacher must have the attitudes and abilities:

\section{a) Professional Teacher Ability}

Excellent schools must have excellent teachers as well. Teachers must have knowledge and skills, have a professional learning community, focus on clear and sustainable learning objectives over a certain period. ${ }^{23}$ The teacher competencies needed by excellent schools are: First: professional competence, second: competence in learning, third: competence in mentoring, fourth: competence in communicating with students, and fifth: competence in evaluating. ${ }^{24}$ Teachers who are professional in learning must take four stages: First: the preparation with the activity of making teacher work programs in the form of compiling learning plans according to the curriculum. Second, implementation; mastering the curriculum and learning tools kit, master subject matter, master the assessment methods and techniques, commitment and discipline. The research conclusions of the OECD team also emphasize that the quality of the delivery system will not go beyond the importance of teacher quality to make students excel. ${ }^{25}$

\section{b) Curriculum}

Excellent schools do not have to use an international standard curriculum. The most important thing in excellent school curriculum is to link subject materials with modern inventions in accordance with current technological developments, then good in mastering Arabic, English and Indonesian langugae. So that, students can communicate their ideas to others well too, which in turn produces an excellent generation.

22 Maswardi, Op.Cit, p. 34.

23 Hopkins \& Jackson, Effective Leadership for School Improvement, New York: Routledge Falmer, 2003, p. 88

24 Ibid, p. 8

25 Dede Rosyada, Madrasah dan Profesionalisme Guru: dalam Arus Dinamika Pendidikan Islam di Era Otonomi Daerah, Jakarta: Kencana, 2017,p. 34. 
In addition, it also implements differentiated education, namely providing educational experiences according to students' interests, talents and intellectual abilities. The term "differentiation" in the sense of a differentiated curriculum refers to a curriculum that is not generally accepted, but it is specifically designed for the needs of certain talent growth and development. A differentiated curriculum is a curriculum specifically designed to serve excellent gifted children with an accelerated, expanded and deepened educational program that gives excellent gifted children the flexibility to learn according to their respective talents, interests and abilities.

c) Extracurricular Program

Excellent schools must have a set of extracurricular activities that can accommodate all abilities, talents and interests of students.

d) Cooperation Network

Excellent schools must have good cooperation networks with various agencies and institutions, especially educational institutions and the development of student competencies.

\section{3) Output}

Excellent schools must produce excellent graduates. The excellence of graduates is not only determined by high test scores. The indication of this excellent graduate can only be known after the person concerned enters the world of work and is actively involved in community life. The resulting ability of graduates is considered superior, if they have been able to develop intellectual, emotional and spiritual potential where they are.

\section{Excellent School Quality Assurance Management}

As mentioned in the introduction, Community Based Management (MBM) and Strategic Management (MS) are types of quality assurance management for excellent schools. The implementation of quality assurance management in excellent schools, should: ${ }^{26}$

\section{a. Creating a Harmonious School Condition (Academic Atmosphere)}

A harmonious school condition is characterized by the establishment of a harmonious relationship among the School Prinicipal and the Teacher, the Teacher and the Teacher, the Teacher and the Students, the Principal and the Parents the Principal and the Community around the school, the Teacher and the Parents and Teachers with the Community around the school. In addition, there are guidance and counseling activities that run smoothly, needed each other both from the teacher, students and parents, and counseling teachers who are skilled in guiding, motivating and directing their students and are

${ }^{26}$ Amin \& Yuliananingsih, Manajemen Mutu, p. 135. 
able to embrace parents to participate in improving quality, a learning process based on Community Based Quality Improvement Management (MPMBM).

\section{b. Supervidon Management Based (Control Management)}

Supervision is one of the elements of school management whose function is being highlighted in controlling the quality of education. Without strict supervision of all educational resources such as teachers, students, facilities and infrastructure, learning resources, libraries and staff, each of them will run independently without control which results in low management quality. The low quality of management also affects the efforts to make schools excel.

In supervision-based management there are two things that needed to be considered:

a) Supervision as a management function carried out by the leadership element. As a management function, the supervision carried out by the leadership is not just a formality but is actually supported by instruments with quality standards. For example, teacher performance, employee performance, human resource discipline, administrative services, learning resources, complete facilities and infrastructure, academic atmosphere that directly touches the students' need at school. If during the supervision there are conditions that do not support excellence, it is necessary to take corrective steps. For example, teachers and students who are not disciplined need to be sanctioned. On the other hand, if teachers and students are much disciplined and are considered to be outstanding, they need to be rewarded;

b) Supervision as a function of evaluating the quality of the continuous learning process (sustainability). Supervision as a function of evaluating the quality of the continuous learning process is intended to evaluate the level of student learning outcomes. If student learning outcomes are high, then the learning process is maintained and can be further improved. On the other hand, if student learning outcomes are low, it is necessary to find the causal factors, whether the cause is teachers, students, learning resources or evaluation instruments (tests). To measure student success can be done continuously, not depending on formative and summative evaluation alone. Strong supervision is indicated by law enforcement (followed by awards and sanctions), reward and punishment, supervision of ball-pick education, quality-based supervision, quality standard supervision of graduates and integrated supervision by all stakeholders.

\section{c. Determination to Improve Sustainable Quality}

Quality is always associated with goods and services (quality of goods and quality of services). Good quality goods and services, positively correlated with high value / price, as well as quality services. The quality of goods or services depends on the characteristics of the goods and services that make the users of the goods and services satisfied. Thus, the quality of goods can be 
interpreted as a combination of characteristics. Education in this case is included in the group of educational services or common services. Therefore, qualified education is education that is able to provide benefits to the school community, both in terms of the learning process (the nature of service) so as to produce quality graduates who are able to satisfy all parties, especially students, parents, the user community including the government. Thus, the determination to improve quality must be nurtured among all school personnel starting from the bottom line (school attendants, for example) to the principal, always the top manager.

The quality of education services with reference to the quality of services above can be measured from several indicators. First: the trust of all parties in education providers. Even though the accepted students donot have high test scores or the average value of their report cards, the learning process was believed to be able to boost students' abilities as well as to produce superior graduates. Second, assuring the ability to excel seen from the appearance of the superior school which is neat, clean and beautiful, sturdy and attractive buldings even though it is not luxurious and expensive and the order that creates its own appeal to the community. Third: the attitude shown by each school personnel who is friendly, polite, attractive so that those served are satisfied. Fourth: responsive to the needs of the community in general and in particular the school community, especially students, teachers and staff, and immediately respond to their complaints and needs.

Efforts to improve quality continuously require a change in attitude, commitment and professionalism of all school personnel. The strategies that must be carried out in continuous quality improvement according to Nanang Fattah are:27

1) Gradual Improvement

Changing the old culture or habits gradually (step by step) which we realize is the wrong step. Another term used in management terminology towards an approach that leads to gradual and continuous improvement is Kaizen, a term that emerged from Japanese management in quality improvement.

\section{2) Cultural Change}

Several things that encourage the conditions for achieving the quality of work related to cultural change are: First: the creation of a conducive work environment, second: Providing adequate facilities and facilities to display optimal work results, third: Creating a clear work mechanism, and fourth: Giving awards (Reward) for the teacher's achievement.

\section{3) Internal Relations}

It takes harmonization of interpersonal relationships, the establishment of a harmonious relationship between individuals in an educational institution.

\footnotetext{
${ }^{27}$ Fattah, Sistem Penjaminan, p. 120.
} 
4) Maintaining Relationship with Stakeholders

Educational institutions are required to always be in touch with interested parties about what they expect from education in these excellent schools. They are students, teachers, community or employment.

5) Internal Troubleshooting

Educational institutions have the obligation to provide varied learning methods for their students if the internal problem is the lack of variations in teacher teaching methods.

6) Role of the Principal

The roles of school principals in featured schools include: First: Principal as leader, Second: Principal as manager, Third: Principal as administrator, Fourth: Principal as educator, Fifth: Principal as entrepreneur, Sixth: Principal as creator of work condition and Seventh: The principal as a supervisor. ${ }^{28}$

\section{d. The school work reference is Productivity (Efficiency and Effectiveness)}

The purpose of school work reference which refers to productivity is to increase competitiveness with schools considered superior. Other schools that excel are considered the initial work standards that must be adhered to. This is where the supervisory role is important to monitor the performance of all personnel from the bottom line to the top line so that they are not below standard in empowering the existing school resources.

In this connection, the learning process in a excellent school should be as excellent or more than the one referred to because its resources are not superior. As proof, the final result of work reference which refers to productivity is the acquisition of high learning outcomes by students which is balanced with high Emotional Quotion (EQ), Social Quotion (SQ), and Spiritual Quotion (SQ).

\section{e. Tough Leadership}

In excellent schools, strong leadership is required, strong leadership is characterized by various abilities:

a. Have a reliable intellectual ability

b. Reliable intellectual abilities are characterized by extensive knowledge, experience in leading, experience in solving problems so that their superiority is recognized by teachers and employees.

${ }^{28}$ Mutohar, Manajemen Mutu, p. 241. 
c. Having endurance abilities which are characterized by persistence in work, persistence in working and being diligent, passionate and disciplined so that they can be used as an example for teachers and employees.

d. Having the ability to control emotions characterized by patience, tolerance, strong worship and trust in God, understanding, right promises, honesty, telling the truth, prioritizing the interests of many people, so that their personality can be used as an example by teachers and excellent school employees.

e. Having the ability to respond quickly to school problems, quickly find problem-solving solutions and the right choice of problem solving alternatives, willing to compete fairly, take advantage of opportunities to advance. Thus, all school members that their leaders have a more reliable one.

f. Having the ability to create new, more productive work systems (innovators) to improve the quality of school resources whose goal is to improve the quality of excellent graduates.

\section{Closing}

This paper seeks to provide an overview of the quality management of excellent school education. Excellent schools are schools that have inferior resources, but produce excellent graduates like those produced by excellent schools. In excellent schools, the process of enhancing students is the main target in achieving quality output. This follows a Systems Theory in Featured Schools expressed by J. Alan Thomas and follows a Process-Output perspective on the strategy to excel schools as suggested by Walls. This paper shows that quality assurance management in excellent schools should: (1) create a harmonious school academic atmosphere (2) management based on supervision (control management) (3) determination to improve sustainable quality (4) the school work refrence is productivity (efficient and effective), and (5) tough leadership. 


\section{Bibliography}

Anonim, Inilah Daftar SMA Unggulan Terfavorite se-Indonesia, http://buahhati.com, Diakses tanggal 12 Januari 2018.

Bambang Sumintono, Sekolah Unggulan: Pendekatan Pengembangan Kapasitas Sekolah, dalam Jurnal Manajemen Pendidikan, Vol. 2 No. 1.

Dede Rosyada, Madrasah dan Profesionalisme Guru: dalam Arus Dinamika Pendidikan Islam di Era Otonomi Daerah, Jakarta: Kencana, 2017.

Direktorat Jenderal Pendidikan Dasar dan Menengah, Data Pokok Pendidikan Dasar dan Menengah SMA Negeri Unggulan Dawai Papua". http:// www.dapo.dikdasmen.kemdkbud.go.id, Diakses Tanggal 12 Januari 2018.

Fasli Jalal, Strategi dan Arah Pengembangan Sekolah Unggul: Dirjen Peningkatan Mutu Pendidik dan Tenaga Kependidikan, Diakses Tanggal 12 Januari 2018.

Hamid Muhammad, Kasta dalam Pendidikan Saatnya Dihapus, http://pressreader.com. Diakses tanggal 12 Januari 2018.

Hatta Saputra, Pengembangan Mutu Pendidikan Menuju Era Global, Bandung: Smile's, 2016.

Hopkins \& Jackson, Effective Leadership for School Improvement, New York: Routledge Falmer, 2003.

Maswardi Muhammad Amin \& Yuliananingsih, Manajemen Mutu Aplikasi dalam Bidang Pendidikan, Yogyakarta: Media Akademi, 2016.

Muhammad, Konsep Pengembangan Sekolah Unggulan, dalam Jurnal, Vol. 4, No. 1.

Nanang Fattah, Sistem Penjaminan Mutu Pendidikan, Bandung: Rosda, 2013.

Petrus Simantara, Sekolah Unggulan: Antara Kenyataan dan Impian, dalam Jurnal Pendidikan Penabur, Vol. 6, No. 08.

Prim Masrokan Mutohar, Manajemen Mutu Sekolah, Jakarta: Aruzzmedia, 2013.

Rohiat, Manajemen Sekolah, Bandung: Refika Aditama, 2008

Veithzal Riva, Education Management. Jakarta: Raja Grafindo, 2009. 
The Role of Education Management in Improving the Quality of Excellent School Education 